\title{
認知ツールの操作スキル向上支援を目的とした \\ Fadable Scaffolding \\ Fadable Scaffolding for Developing Skill in Cognitive Tool for Learning
}

\author{
柏原 昭博 \\ Akihiro Kashihara \\ 電気通信大学大学院情報理工学研究科 \\ Graduate School of Informatics and Engineering, The University of Electro-Communications. \\ akihiro.kashihara@inf.uec.ac.jp, http://wlgate.inf.uec.ac.jp/
}

伊藤 真 ${ }^{11}$

(同上)

Makoto Itoh

macotodice.uec.ac.jp

Keywords: fadable scaffolding, cognitive tool, learning skill, and navigational learning

\section{Summary}

This paper addresses the issue of how to develop skill in operating cognitive tool for learning. Cognitive tool is an interactive application for encouraging learners to visualize/externalize the process or results of learning and to scaffold the learning process as modeled. Such scaffolding enables them to gain cognitive experience of the learning process. Although the learning skill development generally requires the learners to accumulate the cognitive experiences in operating the tool, it would not always induce them to reflect on how they operate it and on how they learn via the tool. Such reflection contributes to learning how to operate the tool, which also involves learning how to learn. In order to provide learners with an opportunity for reflection, this paper proposes fadable scaffolding with cognitive tool, in which functions available on the tool can be faded according to learning skill in a learner-adaptable way. Such fading enables learners not only to accomplish the learning process without the tool but also to gain a proper and deeper understanding of the functions to become more skillful in operating the tool. This paper demonstrates fadable scaffolding with Interactive History (IH for short) for developing skill in operating it, which is a cognitive tool for scaffolding navigation and knowledge construction process in hyperspace provided with unstructured and hypertext-based resources. We have conducted a case study with the fadable scaffolding with IH. The results suggest that the fadable scaffolding allows learners to fade the IH functions in a reasonable way and to become more skillful in operating $\mathrm{IH}$, which would contribute to become more skillful in navigation and knowledge construction process.

\section{1. はじめに}

学び方を学ぶことによって学習スキルの習得や向上 を図ることができると考えられるが，そのためには学び 方にそって学習するという認知的経験を積み重ねること が不可欠である。本論文では，このような観点から，認 知ツールを用いた学習スキル向上支援手法について論じ る.

認知ツールとは，ユーザが自分の認知プロセスに対し て積極的に関与することを前提に, 認知プロセス遂行の 足場を提供するインタラクティブシステムのことであり, 認知プロセスやその成果物を可視化する，あるいは外化 表現させることで認知プロセスの活性化を図ることを目 的としている [Lajoie 00, Kim 07]. 著者らは, こうした 認知ツールを用いて学習プロセスを遂行するスキルを高 める手法について検討してきた [Kashihara 08, Kashihara 09, Kashihara 12].

認知ツールは，通常学習モデルをもとに設計され，モ
デル通りに学習プロセスを遂行できるようにツールの操 作機能が装備される [Jonassen 00, Kashihara 05]. 学 習者は，これらの機能を利用することで学習プロセスの 遂行を認知的に経験することができる。また，学習モデ ルが示唆する「学び方」に習熟して学習プロセスを遂行 するスキル（学習スキル）を向上させるためには，こう した認知的経験を積み重ねて認知ツールの操作に熟達す ることが重要となる[Jonassen 00, Lajoie 00]. 本研究で は，学習モデルにそって学習プロセスを遂行できるよう にツールを操作するスキルを操作スキルと呼び，学習ス キルとは区別して扱う.

一方，この操作スキルの向上を図るためには，ツール を継続的に利用することが必要となるが，単に利用を繰 り返すだけではなく, 学習者が自分自身のツール操作や 操作を通じての学び方を振り返って内省する機会を設け ることが操作スキル向上にとって効果的であると考えら れる. そこで, 著者らは認知ツールの操作機能を段階的 に取り除くという Fadable Scaffolding 手法を提案して

$\dagger 1$ 現在, KDDI 株式会社. 
きた [Kashihara 08, Kashihara 08].

本手法の特徵は, 学習者が自らの学習スキルに応じて 認知ツールの操作機能を段階的に取り除き, 取り除いた 操作機能の対象となる学習プロセスを学習者自身に遂行 させる点にある.このとき, 学習プロセスに行き詰まっ た場合は, 取り除いた機能を再び利用可能とする.こう して操作機能を取り除いていくことは，心的に遂行しな ければならない学習プロセスを徐々に増加させることに なるが，学習プロセスや学び方について考える機会を与 えることになる. また, 学習プロセスの行き詰まりは, 認知ツールの操作機能の必要性や重要性について考える きっかけになると考えられる，これらによって，学習者 は，（1）認知ツールなしでも学習プロセスを遂行するこ とができるようになる，(2) ツール操作に熟達すること になる, という 2 つの面で学習プロセス遂行の向上が期 待できる.

本研究では,これまで Web リソースのような学習向け に十分構造化がなされていないリソースの学習用に開発 してきた認知ツールを用いて, Fadable Scaffolding 手法 を実現し, その有効性を確かめてきた.まず, [Kashihara 08, Kashihara 09]では, 上述した(1)の学習スキル向上 の観点から Fadable Scaffolding の枠組みを検討し, 2 つの異なる認知ツールを用いて, それらの操作機能を中 期的な期間をかけて取り除いていくことで, 最終的に Web ブラウザのみでも学習リソースを効果的に学ぶこ とができるようになる可能性について検証してきた。ま た，(2) については, [Kashihara 12]において認知ツー ルの操作スキルを高める Fadable Scaffolding について 議論し, [伊藤 12] ではその中期的な運用により, ツール の操作スキルが向上する可能性を検証してきた.

本論文の目的は，(2)の認知ツールの操作スキル向上に 焦点をあてたこれまでの研究経緯から得られた成果をと りまとめ, Fadable Scaffolding 手法とその有効性につい て論じることである. 具体的には，ナビゲーションを伴 う学習用の認知ツールとして著者らが開発してきた Interactive History (IH と略す) [柏原 03]の Fadable Scaffolding 手法について詳述する。また, IH における Fadable Scaffolding の実施可能性, および IH の操作ス キル向上について調査したケーススタディについても論 じる.この調査では, 4 週間にわたる Fadable Scaffolding の利用を通して, IH 操作がどう変化するかに着目した. その結果, 学習者自身による操作機能の取り除きが合理 的に行われるとともに, 学習プロセスが促進されるよう に IH 操作が可能となる傾向が示唆された。 また, 本論 文では，新たに Fadable Scaffolding の運用方法につい ても議論する.

以上のように，本論文における Fadable Scaffolding の新規性は，認知ツールの継続的な利用を効果的に支援 してツールの操作スキルを高める点にある。このような アプローチで学習スキルの向上を目指す支援手法は, 関
連研究でも類をみない独創的なものといえる [Kashihara 12].

\section{2. 学習スキル向上支援}

通常，学習スキルを向上させるためには，学習プロセ スの遂行を通して学び方を学ぶ必要がある [Bransford 00].一般に, こうした学習スキル向上の支援では, 想定 する学習モデルから学習プロセス遂行を規定する方略を 同定して，それを教えることで学び方の習得・熟達を図 る場合が多い [Schunk 01, Kayashima 03]. Prompting は，その代表的な支援手法であり，学習中に方略に関す る情報や質問[Narciss 07]を提示することで学び方の学 びを支援するものと捉えることができる.

一方，学び方の学習に対して学習者自身がより積極的 に関与することが学習スキル習得では望ましいとの観点 [Jackson 98] から，著者らは認知ツールを用いた支援に 着目してきた。通常, 認知ツールは, モデル通りに学習 プロセスを遂行できる足場を提供するが，学習プロセス やその成果物を可視化する，あるいは学習者に外化させ ることで学習プロセスを明瞭化・客観視できるようにす るために活用されることが多い [Lajoie 00]. また, 外化 された表現を通じて学習プロセスに対するメ夕認知を活 性化することで，学習スキルの習得を支援する研究も多 く見受けられる [Schunk 01].

本研究における認知ツールを用いた学習スキルの向 上では，適切に学習プロセスを遂行してより良い学習成 果をもたらすことができるように，ツールの操作機能に ついての理解を深めてツール操作に熟達することが肝要 である。そのためには，認知ツールを継続的に利用して 学習プロセス遂行経験を積み重ねる必要がある。しかし ながら，ツール利用を単に繰り返すだけでは効果的に操 作の熟達を図ることは難しく, 学習プロセス遂行や学び 方を考えさせる機会を設けて学習者にツール操作の見直 しを促すことが必要となる。こうした見直しを促すため には，いかに認知的経験を積み重ねさせるかが重要な課 題となる[伊藤 12]. しかしながら, 認知ツールを用いた 認知的経験の積み重ねに関寸る検討は，未だほとんどな されてないのが現状である.

著者らは，これまでに認知的徒弟制の学習観 [Collins 06]に基づき, 学習コミュニティ内で学び方を共有すると ともに，同程度あるいはより高い学習スキルを有する学 習者とのインタラクションを通して学び方を学び合いな がら学習スキルを高める枠組みを提案してきた [Kashihara 08]. また, その枠組みでの一支援として, 認知ツールを用いて学び方に熟達させるための Fadable Scaffolding の考え方を提唱した.

本手法では, 学習者の学習スキルに応じて, 学習者自 身が認知ツールの操作機能を段階的に取り除き

(Fading), その取り除いた機能の対象となる学習プロ セスを学習者に自力で遂行させる. 最終的には, ツール 
なしでも学習プロセスが遂行できるようにすることが目 標となっている.このような操作機能の Fading は，学 習者にかかる認知的負荷を増加させるが, 学習プロセス や学び方を学習者自身が考える機会を与えるという効果 (認知的負荷効果) を生み出すことが期待できる [Sweller 10]. また, 学習者が学習プロセス遂行に行き 詰まった場合は, 再び操作機能を利用可能として (Scaffolding), 学習プロセスを遂行させる.このよう な行き詰まりから, 認知ツールの操作機能の必要性や重 要性についてより深く考えるきっかけを与えるという効 果（行き詰まり効果）が期待できる [Kashihara 12].

これらの効果によって, 学習者は認知ツールの操作ス キルを高めることができると考えられる，同時に，ツー ルなしでも，学び方にそった学習プロセスの遂行が可能 になる.これらは, Fadable Scaffolding の有効性を示す ものであり, Prompting やメタ認知支援では得られにく い.

なお，一般に学習プロセス遂行の足場かけ (Scaffolding) や足場外し (Fading) は, 教授者が学習 者に対して行うものと定義されているが[Collins 06], Fadable Scaffolding では学習者が自分の判断で行う点 で異なる. そこで, 本研究では, 学習者自らツール操作 機能の取り除きあるいは利用可能にすることを, Learner-Adaptable Fading/Scaffolding と呼ぶ.

\section{Fadable Scaffolding の枠組み}

ここでは, Interactive History[柏原 03] を取り上げ て Fadable Scaffolding の枠組みを示す[伊藤 12]. 以下 では，まず IH が想定しているナビゲーションを伴う学 習のモデルを示す. その上で, IH で提供されている操作 機能について説明し, 操作機能を段階的に取り除く（あ るいは利用可能とする） Learner-Adaptable Fading/Scaffoldingについて論じる.

\section{1 ナビゲーションを伴う学習プロセス}

Web リソースのように学習向けに十分構造化されて ないハイパー空間では, 学習目的を達成するため学習者 は主体的にページをナビゲーションしながら, ページご とに学んだ内容を関係づけて知識を構築していく必要が ある [Hill 97, Thuering 95]. また，ナビゲーションプ ロセスでは，次のページを選択する際，ランダムではな く局所的に立てられた目的を満たすように行われる。こ のような局所的な目的は，学習目的のサブゴールと見る ことができ，これをナビゲーション目的と呼ぶ．学習者 はあるページ(始点ページ) で学んだ知識をいかに洗練・ 展開するかをナビゲーション目的として，それを満たす ページ（終点ページ）を見つけることでナビゲーション を進めると考えることができる，著者らは，始点ページ から終点ページに至る 2 ページ間の関係づけを基本ナビ ゲーションプロセス（Primary Navigation Process,
PNP と略す）と呼び，複数のPNP を積み重ねることで 知識が構築されていると考えている. PNP の積み重ねと は，PNP 間で始点ページあるいは終点ページが重なる ことで PNP が関係づけられることを指す. IH では, こ うした PNP の遂行・積み重ねをハイパー空間での学び 方とするモデルを想定しており[柏原 03]，このナビゲー ションを伴う知識構築プロセスを遂行するスキル（知識 構築スキル）を学習スキルと捉えている.

また, このモデルでは, 知識構築プロセスに不十分・ 不適切な点があれば学んだ知識を再構築することも想定 しており，学んだページ内容のリフレクション（始点・ 終点ページで学んだ内容の見直し・再学習), PNP のリ フレクション（ナビゲーション目的，ページ間の関係づ けの見直し・変更), PNP 間のリフレクション (PNP 間 の見直し・再構成）の 3 つの再構築に分けている.

\subsection{Interactive History}

IH は, 上記した知識構築プロセスを遂行可能とするた めに, 図 1 に示すようにナビゲーションプロセス履歴機 能, メモ機能, 知識マップ機能を提供している. 表 1 に, これらの機能と, 各ツール操作の対象となる学習プロセ スの対応関係を示す.

\begin{tabular}{|c|c|}
\hline IH の操作機能 & 対象となる知識構築プロセス \\
\hline メモ機能 & $\begin{array}{l}\text { ・ページ内容の学習 } \\
\text { • 学んだ内容のリフレクション }\end{array}$ \\
\hline $\begin{array}{l}\text { ナビゲーション } \\
\text { プロセス履歴 }\end{array}$ & $\begin{array}{l}\cdot \text { PNP の実行 } \\
\cdot \text { ・実行した PNP のリフレクション }\end{array}$ \\
\hline 知識マップ & $\begin{array}{l}\cdot \mathrm{PNP} \text { の関係づけ } \\
\cdot \mathrm{PNP} \text { 間のリフレクション }\end{array}$ \\
\hline
\end{tabular}

まず，図 1 (a)に示すナビゲーションプロセス履歴では, Web ブラウザを用いて学習者が訪れたページの時系列 を自動生成するとともに, PNP を遂行する場を提供する。 具体的には, 図 1 (d)に示す PNP 入力用のウィンドウを 用いて，学習した任意の 2 ページを始点ページ，終点ペ ージとして, これらのページ間にリンクのアノテーショ ンを行わせる，そして，あらかじめ分類したナビゲーシ ヨン目的リストから学習者に所望の目的を選択させて, 付与したリンクにアノテーションを行わせる. また, 必 要に応じて PNP を変更 (ナビゲーション目的の変更, リンクの変更) ・削除する操作も可能であり，PNPのリ フレクションを遂行することができる.

次に, 図 1 (b)のメモ機能では, ページで学んだ内容を 記録する操作を行わせることで，ページ内容を学ぶ場を 提供する．記録したメモは，ナビゲーションプロセス履 歴上の対応するページにリンクづけされ，いつでも閲覧 することができるようになっている，また，記録したメ モ情報を追記・変更・削除する操作も可能であり, 学ん だ内容のリフレクションを遂行することができる. さらに,ナビゲーションプロセス履歴に含まれる PNP 


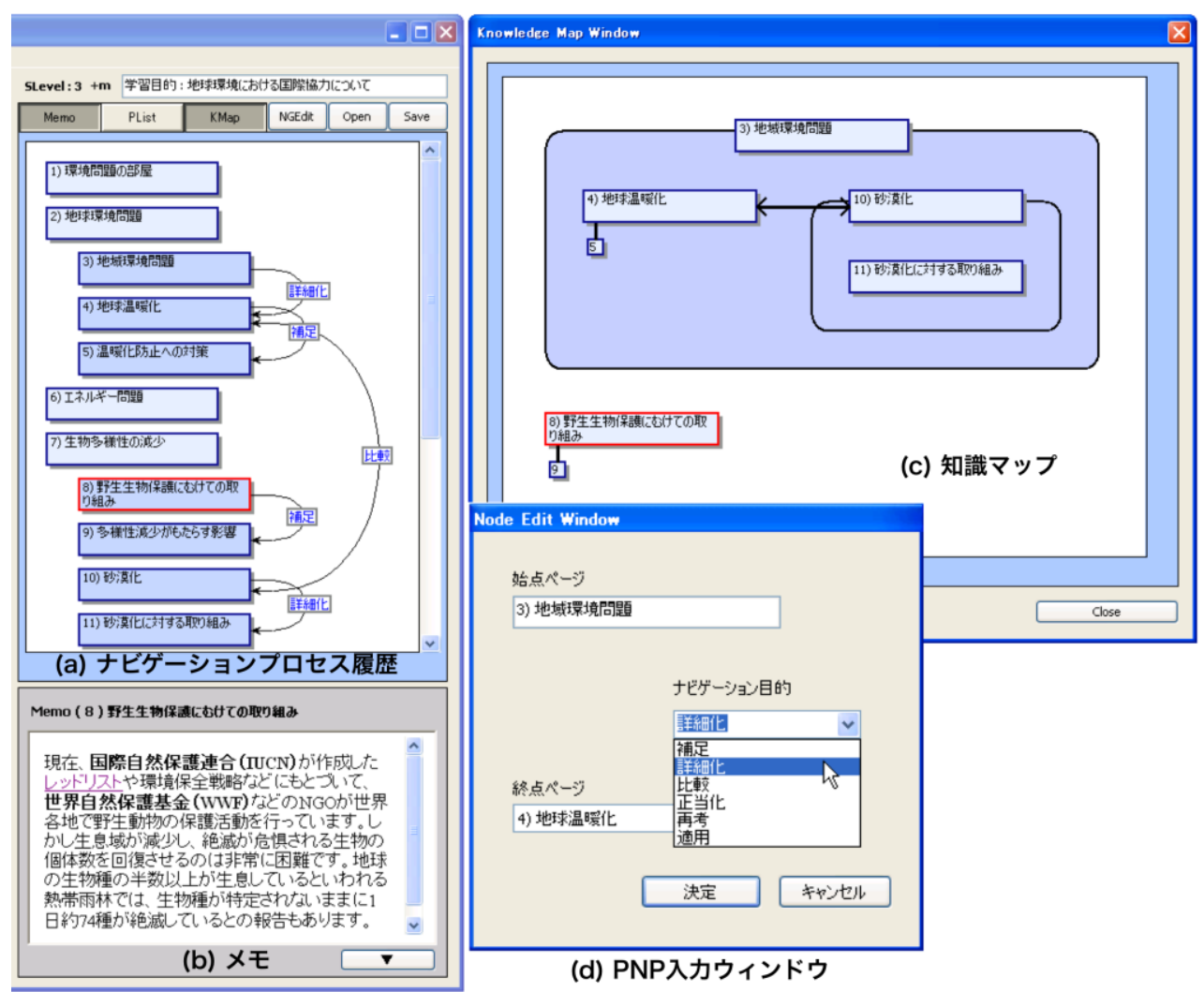

図 1 IH のユーザインタフェース・操作機能

数が増えると, PNP 間の関係を把握するのが困難となる そこで，図 1 (c)に示すように，ナビゲーションプロセス 履歴から自動的に PNP 間の関係を視覚化する知識マッ プ機能を有しており, PNP 間の関係づけの足場を提供す る.（視覚化方法の詳細は[柏原 03]を参照.）

知識マップには, PNPの重なりによっていくつかの島 が形成される。この PNP のまとまりを Knowledge Island（以下，KI と略す）と呼ぶ. 図 1 (c)の知識マップ は, 2 つの KI から構成されており,それぞれ 4 つの PNP と 1 つの PNP を含む. こうした KI に含まれる PNP 数 を, KI の次数と呼ぶ. この次数が大きいほど, PNPの 積み重㸚度合いが高く, 学んだ内容がより多く関係づけ られていることになる.また, PNP 間のリフレションは, 知識マップで PNP 間の関係を見直し, 再構成する必要 がある箇所を確認後, ナビゲーションプロセス履歴上で PNP の変更・削除を行う。

Web ブラウザのみを用いた場合と比較評価した結果, IH を用いることで学んだ内容がより多く関係づけられ て, 学んだ知識の構造化が有意に活性化され, 学習向け に構造化されてないリソースでの学習を効果的に支援で きることが確認されている[柏原 03].

\subsection{Learner-Adaptable Fading/Scaffolding}

図 2 に, IH の操作機能に対する Leaner-Adaptable Fading/Scaffolding の概要を示す。本手法では，学習者 が IH の操作機能を段階的に取り除きながら, PNP の実

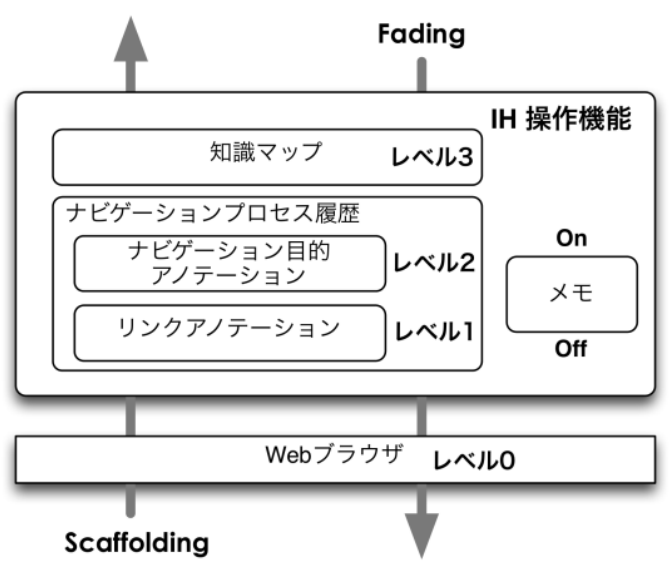

図 2 Learner-Adaptable Fading/Scaffolding

行・積み重ねの経験を積む。操作に行き詰まった場合に は，取り除いた機能を再び利用することができるように なっている. そして, 最終的には Web ブラウザのみで学 習プロセスを遂行できるようになることを目指す.

以上のような Fadable Scaffolding を実現する上で, 操作機能間の依存関係の有無を踏まえて操作機能を取り 除く順序を決める必要がある. IH では, 知識マップはナ ビゲーションプロセス履歴機能で作成される PNP の重 ね合わせに応じて生成されるため, 履歴機能を先に取り 除くと知識マップ機能も利用不可となってしまう。 そこ で，他の機能の遂行に依存する機能は先に取り除くこと 


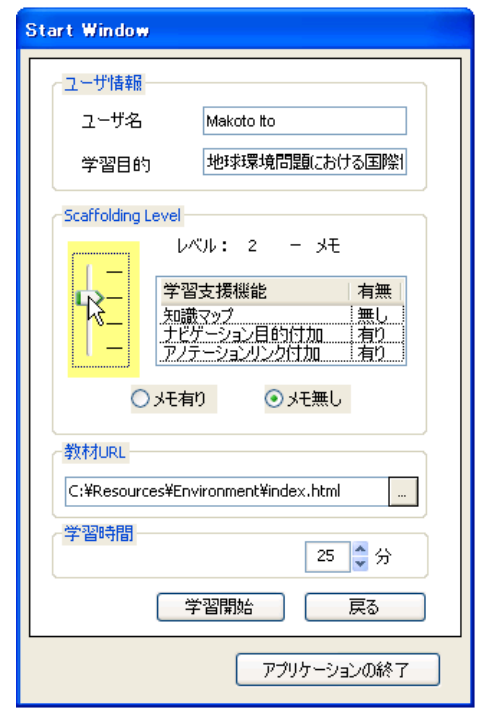

図 3 足場レベル設定・メモ機能の On/Off

としている. IH の場合, 知識マップ機能がナビゲーショ ンプロセス履歴機能の遂行に依存する. さらに，履歴機 能の中ではナビゲーション目的アノテーションがリンク アノテーションの遂行に依存する. そのため, 眓 2 に示 す順に操作機能を取り除く.

一方，メモ機能は, Web ブラウザで閲覧したページに ついて学んだ内容を記録する機能であるため, 他の IH 操作機能の遂行から影響を受けない. このような操作機 能は, 他の機能の Fading とは独立に, Fading/Scaffolding を行うことができる. 図 2 では, メ モ機能の Fading/Scaffolding を, 操作の On/Off として 表現している. なお, メモ機能は学んだ内容自体を記録 するもので, 学習にとっては欠かせないことから Fading の対象外とする考え方もあるが，ここでは他の操作機能 と同様にメモ機能がページ内容の学習やその見直しに重 要かつ必要な役割を果たすことをより深く理解させるた めに Fading の対象とする.

また，本手法では依存関係にある操作機能について， 学習者が利用できる機能の数を足場レベルとしており, IH が学習者に提供する知識構築プロセス遂行のための 足場の高さとみなしている。この足場の高さを徐々に下 げるように操作機能の Fading を行う.

まず，学習者は学習開始時に図 3 に示すユーザインタ フェースで, 足場レベル, メモ機能の On/Off を設定す る. 最初は, IH の全機能（足場レベル 3 ・メモ機能 On） を用いて学習を開始し, 学習者自らどの程度モデル通り に知識構築プロセス遂行を行うことができるかを主観的 に見積り, 知識構築スキルを自己評価した上でメモ機能 の On/Off を切り替えるとともに, 徐々に足場レベルを 下げていく.

図 4 に Fadable Scaffolding の例を示す。図 4 左側は 足場レベル 2 を表し, 右側が足場レベル 1 を表す。いず

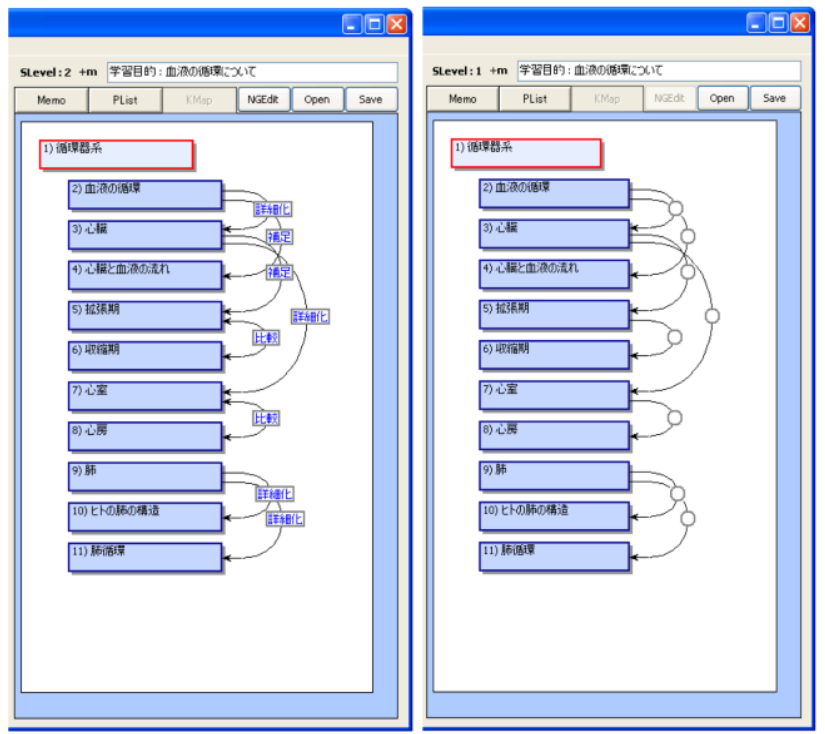

図 4 Fadable Scaffolding の例

れも知識マップ機能が取り除かれているが，レベル 1 で は PNP 遂行のためのリンクアノテーションを行うこと ができるもののナビゲーション目的アノテーション操作 機能が取り除かれている. 学習者は, レベル 2 から 1 人 足場の高さを下げる過程で, PNP の積み重ね操作に加え てナビゲーション目的のアノテーションを心的に遂行す ることが期待される，つまり，足場レベルを徐々に下げ ることで, 心的に遂行しなければならない学習プロセス が増加することになる.

以上のように, Fadable Scaffoldingは, IH の継続的 な利用を通じて学習者が知識構築スキルを自己評価しな がら足場レベルを徐々に下げ，その結果として操作スキ ルの向上を図る手法である.

\section{4. ケーススタディ}

\section{1 実験目的}

ここでは，学習者による Fadable Scaffolding の実施 可能性と, IH を継続的に利用した場合と比較して Fadable Scaffolding が IH の操作スキルに与える影響を 調査することを目的としてケーススタディを実施した. 具体的には, IH の継続的な利用の過程において, 学習者 が知識構築スキルを自己評価し, それに応じて合理的に IH による足場レベルを下げていくことができるかどう かを確認した. また, Fadable Scaffolding の結果, ナビ ゲーションを伴う知識構築が促進されるように IH 操作 が可能となるかどうかを確認した.

なお，学習スキルの向上を評価する場合, 習得された スキルが長期的に保持されるかどうかという視点での評 価と, 一定期間の学習試行（演習や訓練など）後, ある 時点で特定の学習課題を与え, その学習プロセスの遂行 が試行前と比べてどのように変化するかという視点での 
表 2 ケーススタディのセッション構成と日程

\begin{tabular}{|c|c|c|c|c|c|c|c|c|c|c|}
\hline 日程 & \multicolumn{2}{|c|}{ 1日目 } & \multicolumn{2}{|c|}{ 2日目 } & \multicolumn{2}{|c|}{ 3日目 } & \multicolumn{2}{|c|}{ 4日目 } & \multicolumn{2}{|c|}{ 5日目 } \\
\hline \multirow{2}{*}{ セッション } & \multicolumn{2}{|c|}{ プレテスト } & \multicolumn{8}{|c|}{ 学習セッション (2週間) } \\
\hline & テㅈト1 & テスト 2 & セッション1 & セッショョン2 & セッション 3 & セッション4 & セッション 5 & セッション 6 & セッション7 & セッション 8 \\
\hline 学習リソース & 株式投資 & 海の生物 & 茶道 & 循環器系 & 鎌倉時代 & 特許 & 色彩 & 沖縄 & 熱力学 & 原子 \\
\hline 日程 & \multicolumn{2}{|c|}{ 6日目 } & \multicolumn{2}{|c|}{ 7日目 } & \multicolumn{2}{|c|}{ 8日目 } & \multicolumn{2}{|c|}{ 9日目 } & \multicolumn{2}{|c|}{ 10日目 } \\
\hline \multirow{2}{*}{ セッション } & \multicolumn{2}{|c|}{ 中間テス卜 } & \multicolumn{8}{|c|}{ 学習セッション (2週間) } \\
\hline & テ자1 & テスト 2 & セッション9 & セッション10 & セッション11 & セッション 12 & セッション 13 & セッション14 & セッション15 & セッション16 \\
\hline 学習リソース & 株式投資 & ロケット & 循環器系 & 鎌倉時代 & 茶道 & 特許 & 色彩 & 地球環境 & 原子 & 沖縄 \\
\hline 日程 & \multicolumn{2}{|c|}{ 11日目 } & & & & & & & & \\
\hline \multirow{2}{*}{ セッション } & \multicolumn{2}{|c|}{ ポストセッション } & & & & & & & & \\
\hline & テ자 1 & テ자2 & & & & & & & & \\
\hline 学習リソース & 株式投資 & 天気 & & & & & & & & \\
\hline
\end{tabular}

評価の 2 つが考えられる. 本ケーススタディでは, 認知 ツールを用いた関連研究[Jonassen 00, Lajoie 00]でも 一般的に行われている後者の視点から IH の操作スキル 向上を調査した。

\section{2 準備·条件}

本ケーススタディでは, インターネット利用経験 3 年 以上の理工系大学生・大学院生 16 名を被験者として, 表 2 に示すように 4 週間にわたり計 8 日間（表 2 の 2 日 目〜 5 日目と 7 日目〜 10 日目) でIHを利用した学習を 16 セッション実施した. また, 全学習セッションを通し て学習に用いるリソースを 9 つ用意した. 表 2 に, 各学 習セッションで用いた学習リソースを示す.これらのリ ソースに含まれるページ総数は $45 \sim 145$ であり,

Back/Next/Home を除く 1ページあたりの平均リンク数 は2.3〜10.1であった。

また, 全学習セッションを通して Fadable Scaffolding を利用する実験群を FS 群, 利用しない対照群を IH 群 とし，それぞれの条件に被験者を 8 名ずつランダムに割 り当てた. FS 群では, 被験者が自らの知識構築スキル に応じて足場レベルを下げる・上げるという制御を行う ことになると考えられる. また, IH の操作スキルが向上 すると, PNP の実行と積み重ねが促進されて知識が構築 されると考えられる.つまり, 知識マップにおいてより 大きな KI が生成され, PNP 間でより多くの関係が作ら れることになる. Fadable Scaffolding が有効に機能すれ ば，こうした傾向が IH 群よりも FS 群に強く現れると 考えられる.

これらの点を踏まえて, 本ケーススタディでは次のよ うな仮説を立てた。

H1 : FS 群では IH による足場レベルを合理的に下げて いくことができる

H2 : Fadable Scaffolding は, PNP 実行・積み重ね操作 をより促進する.

\section{3 手順}

本ケーススタディでは, 表 2 に示すように 16 の学習
セッションのほか, 学習セッションの前・中間・後に IH の操作スキルを確認することを目的として，3 つのテス ト（プレテスト, 中間テスト, ポストテスト） セッショ ンを実施した.

まず，学習セッションは 1 日 2 セッション行い, 両群 に対してセッションごとに同じ学習リソースと同じ学習 目的を与え, IH を用いて学ばせた. 各セッションの制限 時間は 25 分とした. なお, 学習目的はセッション毎に 異なるように設定した. セッション終了後,「各ページで 理解した内容を関係づけながらうまく知識を構築できま したか (はい/いいえ)」といった知識構築プロセス遂行 の成否に関するアンケートに答えさせた.このアンケー トの目的は, 学習者に知識構築スキルの自己評価を促す ことにある.

また, 各セッションでは, FS 群の被験者に対しての み,「自分のスキル習得状況に応じて足場レベル, メモ機 能の On/Off を制御し, 最終的には全操作機能を取り除 いた状態で学習できるようになることを目指してくださ い」といった指示を与えた。 また，各セッション開始時 に, 直前のセッションで生成したナビゲーションプロセ ス履歴を確認させた後, 足場レベルとメモ機能の On/Off を設定させた。なお, セッション中は操作機能の Fading/Scaffoldingは禁止した.

次に, テストセッションでは, FS 群, IH 群の両群と もに IH の全操作機能を用いて学習リソースを学ぶテス トを実施した。テストセッションの間隔については，表 2 の通りプレテストと中間テストの間および中間テスト とポストテストの間がいずれも 2 週間となるように設定 した. また，3つのテストセッションで同じリソース（株 式投資) を学ぶテスト 1 と, 異なるリソース（ドメイン： 海の生物, ロケット, 天気）を学ぶテスト 2 を実施し, それぞれのプレテストから中間・ポストテストへの IH 操作の変化を分析することにした. 表 3 に, テスト用に 用いた 4 つのリソースのドメイン, 総ページ数,

Back/Next/Home を除く1ページあたりの平均リンク数 を示す.

各テストセッションでの 2 つのテストは 1 日で行い, 


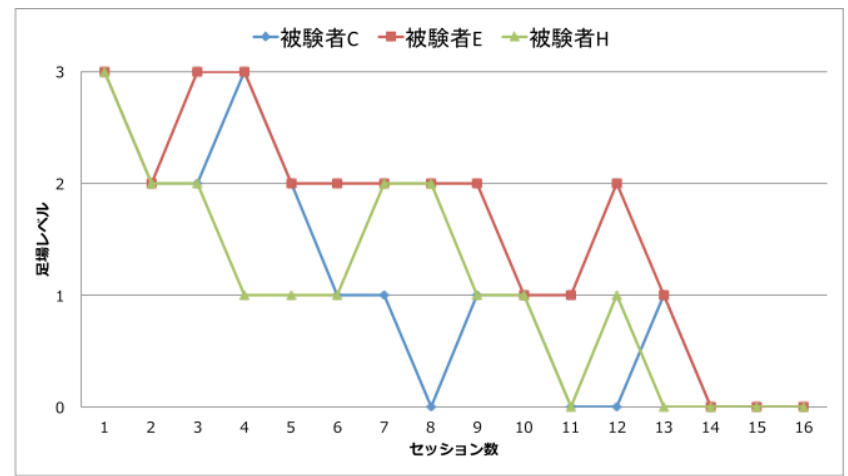

(a) 緩やかな変更

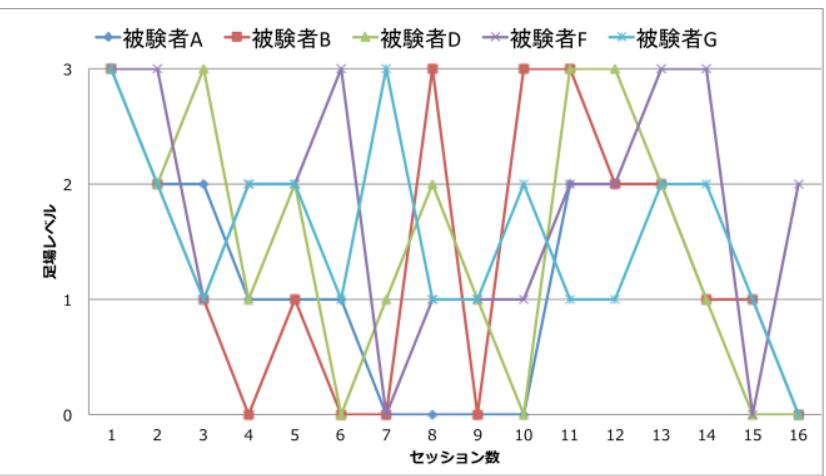

(b)頻繁な変更

図 5 足場レベルの推移

制限時間をそれぞれ 25 分とした.また, テスト 1 では, 同じリソースを学ぶため, 異なる学習目的としてプレテ ストでは「株式に関する情報の入手方法について学ぶこ と」, 中間テストでは「株式投資のメリットについて学ぶ こと」, ポストテストでは「株式が稼ぎにつながる理由に ついて学ぶこと」を与えた.

表 3 テストセッションで用いた学習リソース

\begin{tabular}{|c|c|c|c|c|}
\hline & テスト 1 & \multicolumn{3}{|c|}{ テスト 2} \\
\hline 学習リソース & 株式投資 & 海の生物 & ロケット & 天気 \\
\hline 総ページ数 & 83 & 56 & 56 & 52 \\
\hline 平均リンク数 & 4.3 & 4.0 & 4.2 & 4.3 \\
\hline
\end{tabular}

なお，プレテストセッション開始前に，両群の被験者 に対して IH が想定している学習モデルと, IH の操作方 法について説明した. この際, ペーパーマニュアルを用 意することで, 被験者間で IH に関する説明に差が出な いように留意した．被験者には「ネットワーク」に関す るリソースを与え, 説明に沿って実際に IH を操作させ た.

以上の手順で得られる知識構築プロセス遂行の成否 に関するアンケート結果と, テストセッションでの IH 操作履歴としてナビゲーションプロセス履歴・知識マッ プから，(1）実行された PNP 数，(2) 知識マップにおけ る KI の最大次数 (KI が含む PNP の最大值), (3) PNP の重なり度 (次数 2 以上の $\mathrm{KI}$ に含まれる $\mathrm{PNP}$ 数の平均 值）に関するデータを収集した。

\section{4 実験結果·考察}

\section{§ 1 Fadable Scaffolding 実施可能性について}

まず, 仮説 $\mathrm{H} 1$ を確かめるために, 図 5 に FS 群の被 験者 8 名による 16 の学習セッションにおける足場レベ ルの推移を示寸. 図からも分かる通り, 全被験者におい て足場レベルが 0 まで下がっていたことがうかがえる. また, 足場レベルの推移には 2 つの傾向があることが分 かった，それは，図 5 (a)に示すように 16 セッションに わたり足場レベルを緩やかに下げる傾向と, 図 $5(\mathrm{~b})$ に示
すように 16 セッションにわたり足場レベルを 3 から 0 の間を頻繁に上下させたり，一度に 2 段階以上足場レベ ルを変更したりする傾向の 2 つである. これは, 独立し た操作機能であるメモ機能の取り除き方に関係している と考えられる。つまり, 図 5 (a)の被験者群はメモ機能の 有無を頻繁に変更する傾向にあったことから, 各足場レ ベルにおいてメモ機能が Off となる影響を考慮しながら, 足場レベルを徐々に下げていたのではないかと推察され る. 一方, 図 $5(\mathrm{~b})$ に示した被験者群は連続する複数セッ ションでメモ機能の有無を保つ傾向にあったことから, メモ機能ありあるいはなしにおいて, 足場レベルを変更 した場合の影響を見極めようとしていたのではないかと 考えられる. また，より挑戦的に足場レベルの変更を行 おうとしていたこともうかがわれる.

さらに, 表 4 に各セッション終了後に収集した知識構 築プロセス遂行に関するアンケート結果を示す.このと き, 知識構築がうまく行えたという「はい」の回答数と 「いいえ」回答数には, $1 \times 2$ 直接確率検定の結果 $1 \%$ の有意差（両側検定 : $\mathrm{p}=0.003$ ）が見られた.

表 4 知識構築プロセス遂行の可否

\begin{tabular}{|c|c|}
\hline アンケート結果 & 回答数 \\
\hline はい & 81 \\
\hline いいえ & 47 \\
\hline 合計 (16セッション $\times 8$ 名=128) & 128 \\
\hline
\end{tabular}

表 5 隣接するセッション間でのアンケート回答の推移

\begin{tabular}{|c|c|c|c|}
\hline セッションnでの回答 & セッション n+1 での回答 & & \\
\hline はい & \multirow{2}{*}{ はい } & 46 & \multirow{2}{*}{76} \\
\hline いいえ & & 30 & \\
\hline はい & \multirow{2}{*}{ いいえ } & 32 & \multirow{2}{*}{44} \\
\hline いいえ & & 12 & \\
\hline 合計 $(15 t$ & ヨン間 $\times 8$ 名=120) & & 120 \\
\hline
\end{tabular}

次に, 表 5 に隣接するセッション間における知識構築 プロセス遂行に関するアンケート回答の遷移結果を示す. このとき, 知識構築をうまく行えるように遷移した回数 とうまく行えなくなった遷移回数には， $1 \%$ の有意差（1 $\times 2$ 直接確率検定・両側検定, $\mathrm{p}=0.005)$ が見られた.さ らに, 表 6 に回答の遷移ごとに足場レベルの変化量と, 
その該当セッション数を示す。ここでは，セッション間 の足場レベル変化量が士 1 以内の変更を合理的とし，か つセッションnでの回答が「はい」（あるいは「いいえ」） の場合知識構築がうまく行えたと自己評価したことから， セッション $\mathrm{n}+1$ では足場レベルを維持または一つ下げ ること（あるいは知識構築がうまく行えなかったと自己 評価したことから, セッション $\mathrm{n}+1$ では足場レベルを維 持または一つ上げること）が合理的な変更と考えて集計 した. その結果, 合理的な変更がなされたセッション数 が 90, 合理的でない変更がなされたセッション数が 30 となり， $1 \%$ の有意差が見られた $(1 \times 2$ 直接確率検定・ 両側検定, $\mathrm{p}=0.000$ ).

表 6 回答遷移と足場レベルの変更量

\begin{tabular}{|c|c|c|c|}
\hline $\begin{array}{l}\text { セッション } \\
\mathrm{n} \text { での回答 }\end{array}$ & $\begin{array}{c}\text { セッション } \\
n+1 \text { での回答 }\end{array}$ & $\begin{array}{c}\text { 足場レベルの } \\
\text { 変更 }\end{array}$ & $\begin{array}{c}\text { 該当 } \\
\text { セッショ数 } \\
\end{array}$ \\
\hline \multirow{6}{*}{ はい } & \multirow{3}{*}{ はい } & $+1 \sim$ & 9 \\
\hline & & $-1 \sim 0$ & 35 \\
\hline & & $\sim-2$ & 2 \\
\hline & \multirow{3}{*}{ いいえ } & $+1 \sim$ & 0 \\
\hline & & $-1 \sim 0$ & 27 \\
\hline & & $\sim-2$ & 5 \\
\hline \multirow{6}{*}{ いいえ } & \multirow{3}{*}{ はい } & $+2 \sim$ & 3 \\
\hline & & $0 \sim+1$ & 20 \\
\hline & & $\sim-1$ & 7 \\
\hline & \multirow{3}{*}{ いいえ } & $+2 \sim$ & 0 \\
\hline & & $0 \sim+1$ & 8 \\
\hline & & $\sim-1$ & 4 \\
\hline
\end{tabular}

は合理的な足場変更を表す

表 7 回答遷移とメモ機能の On/Off 切替え

\begin{tabular}{|c|c|c|c|}
\hline $\begin{array}{l}\text { セッション } \\
\text { n での回答 }\end{array}$ & $\begin{array}{c}\text { セッション } \\
n+1 \text { での回答 }\end{array}$ & $\begin{array}{c}\text { xモ機能の } \\
\text { On/0ff }\end{array}$ & $\begin{array}{c}\text { 該当 } \\
\text { セッショ数 }\end{array}$ \\
\hline \multirow{6}{*}{ はい } & \multirow{3}{*}{ はい } & On & 4 \\
\hline & & 維持 & 33 \\
\hline & & Off & 9 \\
\hline & \multirow{3}{*}{ いいえ } & On & 8 \\
\hline & & 維持 & 19 \\
\hline & & Off & 5 \\
\hline \multirow{6}{*}{ いいえ } & \multirow{3}{*}{ はい } & On & 4 \\
\hline & & 維持 & 19 \\
\hline & & Off & 7 \\
\hline & \multirow{3}{*}{ いいえ } & On & 0 \\
\hline & & 維持 & 9 \\
\hline & & Off & 3 \\
\hline
\end{tabular}

は合理的な足場変更を表す

また, メモ機能についても，表 6 と同様に合理的な On/Off 切替えを集計した. 表 7 にその結果を示す. 合理 的な切替えがなされたセッション総数は 98 となり, 合 理的でない切替え（総数 22）との間に有意な差が見られ た $(1 \times 2$ 直接確率検定・両側検定, $\mathrm{p}=0.000)$.

以上の結果から, 仮説 H1 のとおり, FS 群では被験者 による知識構築スキルに対する自己評価に基づいて合理 的に IH による足場レベルを下げていくことができてお $り$, Learner-Adaptable Fading/Scaffolding の実施可能 性が示唆されたと考えられる.

\section{§ $2 \mathrm{IH}$ の操作スキルについて}

次に, 仮説 2 を確かめるために, 表 8 に各テストセッ ションにおいて FS 群・IH 群で遂行された PNP 数, 生 成された KI の最大次数，および $\mathrm{PNP} の$ 重なり度の平 均を示寸。なお，テスト 2 では，プレテストで FS 群と $\mathrm{IH}$ 群の間に, PNP 数, KI の最大次数, PNP の重なり 度いずれにおいても有意差が見られたことから，今回の 分析ではテスト 2 を対象外として, テスト 1 のみ分析対 象とした。

各テストセッションにおける FS 群と IH 群を比較す ると, PNP 数について中間テストで FS 群のほうが有意 に大きくなった（片側検定， $\mathrm{t}(14)=2.32, \mathrm{p}<.05)$. また， KI の最大次数については中間テストで，PNP の重なり 度についてはポストテストでそれぞれ FS 群が大きくな る傾向が見られた（片側検定， $\mathrm{t}(10)=1.43, \mathrm{p}<0.10$, $\mathrm{t}(9)=1.53, \mathrm{p}<0.10)$. その他の箇所では有意差は見られな かった. ポストテストでの PNP 数, $\mathrm{KI}$ の最大次数に ついても有意差は見られなかったが，FS 群がより高い 值となった。

表 8 テストセッション（テスト1）の結果

\begin{tabular}{|c|c|c|c|c|}
\hline & テスト1 & PNP 数 & KI の最大次数 & PNP 重なり度 \\
\hline & プレテスト & $\begin{array}{c}17.6 \\
(6.65)\end{array}$ & $\begin{array}{c}5.38 \\
(1.85)\end{array}$ & $\begin{array}{c}4.54 \\
(1.00)\end{array}$ \\
\hline FS 群 & 中間テスト & $\begin{array}{l}28.5^{*} \\
(12.6)\end{array}$ & $\begin{array}{l}9.00 \dagger \\
(4.47)\end{array}$ & $\begin{array}{c}7.50 \\
(3.84)\end{array}$ \\
\hline & ポストテスト & $\begin{array}{c}29.3 \\
(15.0)\end{array}$ & $\begin{array}{c}13.6 \\
(9.29)\end{array}$ & $\begin{array}{l}11.5 \dagger \\
(7.66)\end{array}$ \\
\hline & プレテスト & $\begin{array}{c}15.1 \\
(2.70)\end{array}$ & $\begin{array}{c}6.13 \\
(4.76)\end{array}$ & $\begin{array}{c}4.94 \\
(2.26)\end{array}$ \\
\hline IH 群 & 中間テスト & $\begin{array}{c}16.8 \\
(6.71) \\
\end{array}$ & $\begin{array}{c}6.50 \\
(2.07) \\
\end{array}$ & $\begin{array}{c}7.20 \\
(3.34) \\
\end{array}$ \\
\hline & ポストテスト & $\begin{array}{c}27.5 \\
(20.3)\end{array}$ & $\begin{array}{c}9.75 \\
(6.80)\end{array}$ & $\begin{array}{c}7.10 \\
(2.56)\end{array}$ \\
\hline
\end{tabular}

One-sided t-test *:p<0.05, †:p<0.10（）内は標準偏差

次に, 各群のプレテスト・中間テスト・ポストテスト 間を比較した. 図 6 に示すように, FS 群ではプレテス トからポストテストにかけて, PNP 数, KI の最大次数, PNP の重なり度いずれの值も有意により大きくなる傾 向にあることが分かった。

以上の結果から，株式投資の学習リソースを学ぶとい う限定された範囲ではあるが, IH の継続的利用における Fadable Scaffolding の実施によって，仮説 H2 のとお りPNP の実行・積み重齐が促進され, 知識構築を遂行 するための IH 操作スキルが向上する可能性が示唆され たと考えられる.

さらに, $\mathrm{IH}$ 操作スキルの向上について分析するために, プレテストにおける PNPの重なり度の值でFS群を上位 群（FS-H群）4名と下位群（FS-L 群）４名の 2 群に分 けた，その上で，各群のプレテスト・ポストテスト間を 比較した。そその結果を図 7 に示す，FS-H 群では，KIの 最大次数が大きくなる傾向が見られた（両側検定, $\mathrm{t}(3)=2.40, \mathrm{p}<.10)$. FS-L 群では, KI の最大次数, PNP 


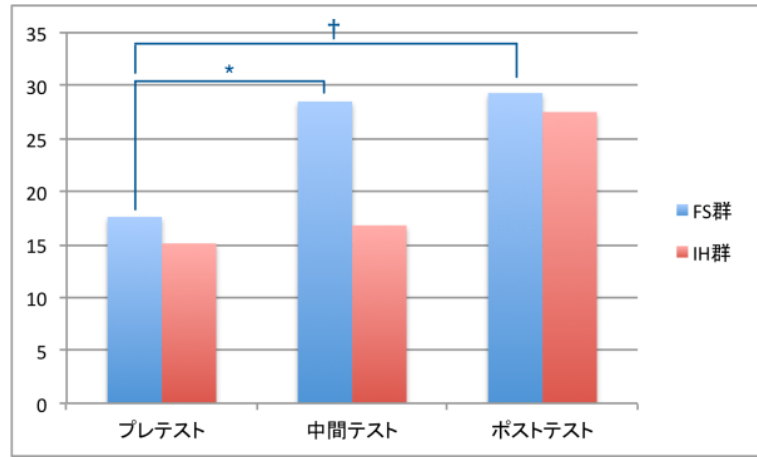

(a) PNP数

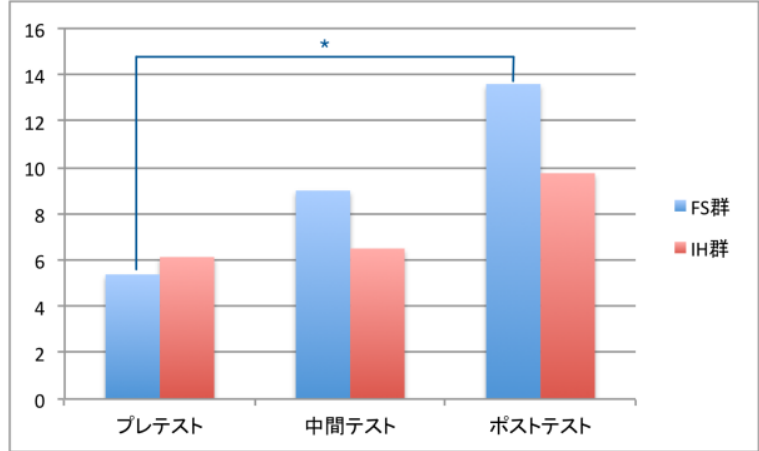

(b) KIの最大次数

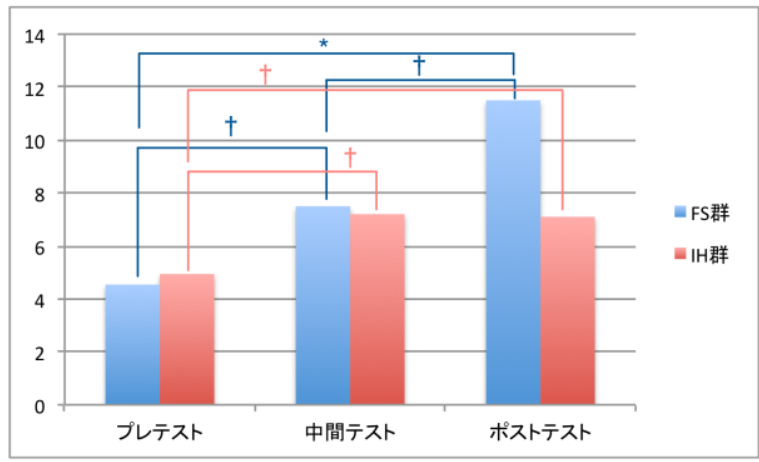

(c) PNPの重なり度

Two-sided t-test * $: p<0.05, \dagger: p<0.10$

図 6 各群におけるテスト間の有意差

の重なり度において有意な差が見られた（KI の最大次 数 : 両側検定, $\mathrm{t}(3)=3.29, \mathrm{p}<.05 ; \mathrm{PNP}$ の重なり度 : 両 側検定, $\mathrm{t}(3)=3.07, \mathrm{p}<.10)$.

これらの結果から, FS-L 群の方が IH 操作スキルをよ り高める傾向にあることがうかがわれる.つまり, IH 利 用開始時にうまく PNP の積み重ねがなされていかなっ た学習者に対して, Fadable Scaffolding がより有効に機 能する可能性が示唆されたと考えられる.

\begin{tabular}{|c|c|c|c|}
\multicolumn{2}{c}{ 表 9} & 妥当でない PNP の割合 \\
\hline & プレテスト & 中間テスト & ポストテスト \\
\hline FS 群 & 0.0132 & 0.00347 & 0.00227 \\
\hline IH 群 & 0 & 0.00463 & 0.00431 \\
\hline
\end{tabular}

なお, 参考として, 各テストセッションで遂行された PNP の遂行が妥当であったかどうかを確かめるために,

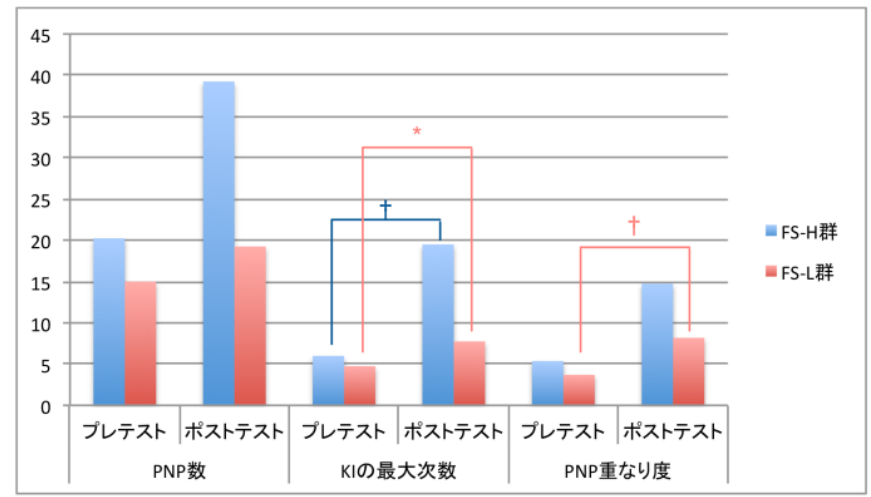

Two-sided t-test * $: p<0.05, \dagger: p<0.10$

図 7 FS-H 群 /FS-L 群の比較

始点・終点ページ間に直接リンク（同一ページへのリン クも含む) がなく, かつページごとに学んだ内容を関係 づける上で両ページに記載された項目の関連度が低いと 著者らが判断した PNP の割合を調べた。 その結果, 表 9 に示すように, 該当する PNP はほとんどなかった. このことから，各テストセッションでの PNP 遂行はほ ぼ妥当なものであったと考えている.

\section{5. 議論}

ここでは, 提案した Fadable Scaffolding の運用可能 性について議論する.

\section{1 足場レベルの設定}

今回のケーススタディでは, Learner-Adaptable Fading/Scaffolding がおおむね合理的に行われることを 確認したが，学習者による主観的な学習スキルの自己評 価に依拠して足場レベルを設定するのではなく，学習者 の学習スキルを推定した上でより適切な足場レベルを設 定するという方式も考えられる。このような適応的な支 援によって, より効果的に Fadable Scaffolding を運用 することができると考えられるが，学習スキル推定をい かに行うかという課題を解決する必要がある.

ただし，本論文で述べた Fadable Scaffolding では, 学習者による学習スキルの自己評価が不的確で足場レベ ルが低く設定された場合でも, 認知ツールの操作に行き 詰まりが起こる可能性が高まるが, 取り除いた機能を再 度利用することができ, またその機能の必要性や重要性 について考えるきっかけを学習者に与えることになると 期待できる. 操作スキルの向上という観点からすると, 適切に足場レベルが設定されることは望ましいが，学習 者による自己評価が不的確であっても Fadable Scaffolding の運用上大きな問題にはならないと考えて いる.

\section{2 足場変更のタイミング}

ケーススタディでは, 足場レベルの変更, メモ機能の 
On/Off 切替えはセッションごとに学習を終えるまで禁 止し, 新たなセッション開始時に足場の変更を行わせて いた。 これは，設定した足場の影響を調べることが目的 であったためである。

一方，学習中に認知ツール操作に行き詰まった場合， その機能の必要性や重要性を認識させ, かつ操作の仕方 やそれを通じた学び方を学ばせるために, 即応的に取り 除いた機能を再度利用可能としたり, 行き詰まったとし ても極力学習者自身に考えさせるように仕向けたりする ことが必要になる．こうした足場変更のタイミングをい かに適応的に決めるかは, より的確なスキル向上支援の 実現にとって重要な課題になると考えられる.

\section{6. まとめ}

本論文では, 認知ツールを用いた学習スキル向上を目 指し, ツール操作スキルの向上を図る支援手法として Fadable Scaffolding について論じた. 特に, 認知ツール の操作機能を段階的に取り除き, 操作機能の必要性や重 要性を考えさせる機会を与えることでツール操作のスキ ルを高めることについて述べた。

また, ナビゲーションを伴う学習向けの認知ツールを 題材として, Fadable Scaffolding の実施可能性および操 作スキルへの影響を調べたケーススタディについて述べ, 4 週間の試行において合理的に操作機能を取り除くこと ができる可能性が示唆されるとともに, 単一の学習リソ 一スを異なる学習目的で学ぶという限定された範囲内で 認知ツールの操作スキルが高まる可能性が知見として得 られた。

今後は，より大規模かつ長期的な評価実験を実施して, より多様な学習リソースを用いて認知ツールの操作スキ ル向上を評価するとともに, 習得された操作スキルの保 持という視点からも評価を実施していきたい. また，そ の結果に基づき, Fadable Scaffolding の問題点を洗い出 し，手法を洗練したいと考えている. 特に，今回のケー ススタディでは, 認知ツールの全機能を Fading の対象 としたが, IH のメモ機能のようにツールの中でも学習に とって欠かせないような基盤となる機能も Fading の対 象とするべきかどうかについて検討を進めていきたいと 考えている. また, 現在, 本手法を他の認知ツールにも 応用しており [大石 13], これからも様々な認知ツール に適用することで本手法の汎用性について検討を進めた い.

\section{謝辞}

本研究の初期段階で Fadable Scaffolding の設計に貢 献してくれた真谷真之氏, 沢崎和郎氏に感謝する. なお, 本研究の一部は JSPS 科研費基盤研究 (B)(No.23300297)・(No.26282047)の援助による.

\section{$\diamond$ 参考文献 $\diamond$}

[Bransford 00] Bransford, J. D., Brown, A. L., and Cocking, R. R. (eds.): How People Learn - Brain, Mind, Experience, and School, National Academy Press (2000).

[Collins 06] Collins, A.: Cognitive apprenticeship: The Cambridge Handbook of the Learning Sciences, R. Keith Sawyer (Ed.), pp.47-60, Cambridge University Press (2006).

[Hill 97] Hill, J. R. and Hannafin, M. J.: Cognitive strategies and learning from the World Wide Web, Educational Technology Research and Development, Vol.45, No.4, pp.37-64 (1997).

[伊藤 12] 伊藤真, 柏原昭博: 認知ツールを用いた学習 スキルアップのための Fadable Scaffolding 手法と その評価,教育システム情報学会研究報告, Vol.26, No.7, pp.95-102 (2012).

[Jackson 98] Jackson, S. L., Krajcik, J., and Soloway, E.: The Design of Guided Learner-Adaptable Scaffolding in Interactive Learning Environments, CHI 98, pp.187-194 (1998).

[Jonassen 00] Jonassen, D. H.: Computers as Mindtools for Schools: Engaging Critical Thinking, Second Edition, Prentice-Hall (2000).

[柏原 03] 柏原昭博, 坂本雅直, 長谷川忍, 豊田順一：八 イパー空間における主体的学習プロセスのリフレ クション支援，人工知能学会論文誌，Vol.18, No.5, pp.245-256 (2003).

[Kashihara 05] Kashihara, A. and Hasegawa, S.: A Model of Meta-Learning for Web-based Navigational Learning, International Journal of Advanced Technology for Learning, Vol.2, No.4, pp.198-206 (2005).

[Kashihara 08] Kashihara, A., Sawazaki, K., and Shinya, M.: Learner-Adaptable Scaffolding with Cognitive Tool for Developing Self-Regulation Skill, Proc. of the 16th International Conference on Computers in Education, pp.133-140 (2008).

[Kashihara 09] Kashihara, A. and Taira, K. Developing Navigation Planning Skill with Learner-Adaptable Scaffolding, Proc. of AIED 2009, pp.433-440 (2009).

[Kashihara 12] Kashihara, A. and Ito, M.: Fadable Scaffolding with Cognitive Tool, Proc. of ITS2012, LNCS Vol. 7315, pp.662-663 (2012).

[Kayashima 03] Kayashima, M. and Inaba, A.: Towards Helping Learners Master Self-Regulation Skills. Supplementary Proceedings of AIED2003, pp.602-614 (2003).

[Kim 07] Kim, B. and Reeves, T. C.: Reframing research on learning with technology: in search of the meaning of cognitive tools, Journal of Instructional Science, Vol.35, pp.207-256 (2007).

[Lajoie 00] Lajoie, S. P. (ed.): Computers As Cognitive Tools: No More Walls: Theory Change, Paradigm Shifts, and Their Influence on the Use of Computers for Instructional Purposes 2nd ed. Lawrence Erlbaum Assoc. Inc. (2000). 
[Narciss 07] Narciss, S., Proske, A., and Koerndle, H.: Promoting self-regulated learning in web-based learning environments, Computers in Human Behavior, Vol.23, No.3, pp.1126-1144 (2007).

[大石 13] 大石千恵, 柏原昭博: Web 調べ学習における 課題展開を活性化するための Fadable Scaffolding, 教育システム情報学会研究会 Vol.28, No.3, pp.17-24(2013).

[Schunk 01] Schunk, D. H. and Zimmerman, B. J. (eds.): Self-Regulated Learning and Academic Achievement: Theoretical Perspectives, 2nd ed. Lawrence Erlaum Assoc (2001).

[Sweller 10] Sweller, J.: Cognitive Load Theory: Recent Theoretical Advances. In J.L Plass, R. Moreno, and R. Bruenken (ed.): Cognitive Load Theory, pp.29-47, Cambridge University Press (2010).

[Thuering 95] Thuering, M., Hannemann, J., and Haake, J. M.: Hypermedia and cognition: Designing for comprehension, Communication of the ACM, Vol.38, No.8, pp.57-66 (1995).

[担当委員 : 吉川 厚]

2014 年 7 月 23 日 受理

\section{一著 者 紹 介}

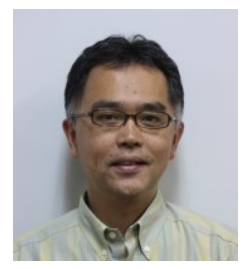

柏原 昭博（正会員）

1987 年徳島大学工学部情報工学科卒業. 1989 年同大学院修士課程修了. 1992 年大 阪大学大学院博士課程修了. 大阪大学産 業科学研究所助手, 講師, 助教授を経て, 2003 年電気通信大学情報通信工学科助 教授, 2007 年同准教授, 2011 年同大学院 情報理工学研究科教授，1996 1997 年，ドイツ GMD-FIT 客員 研究員, 現在に至る. 博士(工学). 学習工学, 特に学習プロセ スのモデル化および学習ツールに関する研究に従事. 1993 年本 学会全国大会優秀論文賞, ED-MEDIA'95 優秀論文賞, 1996 年 度・1998 年度・2005 年度・2009 年度・2012 年度本学会研究会 優秀賞, 教育システム情報学会第 33 回全国大会研究奨励賞, IJAIED, 電子情報通信学会, 情報処理学会, 日本教育工学会各 会員.

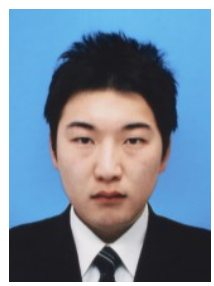

伊藤 真

2010 年電気通信大学電気通信学部情報 通信工学科卒業, 2012 年同大学院情報理 工学研究科総合情報学専攻博士前期課程 修了. 現在 KDDI 株式会社. 在学中, 認 知ツールによる学習支援の研究に従事. 